Available online at : http://journal.unj.ac.id/unj/index.php/gjik

Gladi : Jurnal Ilmu Keolahragaan 12 (01) 2021, 48-54

Permalink/DOI: https://doi.org/10.21009/GJIK.121.06

\title{
ANALYSIS OF BATTING CRICKET EXERCISES BEGINNERS JAKARTA'S ATHLETES U-17
}

\author{
Mastri Juniarto $^{1}$, Rizky Nurulfa ${ }^{1}$ \\ ${ }^{1}$ Pendidikan Jasmani, Universitas Negeri Jakarta \\ Faculty of Sport JL Pemuda, No. 10, Rawamangun,Kota East Jakarta 13220 \\ Corresponding aouthor. Email: mastri@unj.ac.id
}

\begin{abstract}
Batting is a major component in the game of Cricket. Batting is collecting value by hitting the ball and holding the ball and running to swap places with other runners, and if the ball hits the stump then the batsman is declared out. This study discusses the analysis of batting techniques in the game of Cricket U-17 beginner athletes in DKI Jakarta. The subjects in this study were novice athletes from Jakarta U-17 athletes, who were junior high and high school students who had just joined the cricket team. The method in this research uses descriptive qualitative research. With a sample of 60 athletes who are members of the Jakarta U-17 beginner athletes. The results showed that, it showed that the category of batting training facilities and infrastructure for U-17 athletes in DKI Jakarta was $86.04 \%$ on average. These results illustrate that batting facilities and infrastructure are in very good category. Furthermore, in the category of results of the application of batting training for U-17 athletes in DKI Jakarta, it shows that the average is $74.94 \%$. These results illustrate that the application of batting in the category is good and the results of batting for U-17 athletes in DKI Jakarta show that the average is $53.36 \%$. These results illustrate that the batting in the category is sufficient. The results of field observations and analysis in the Batting Cricket exercise are explained as follows: 1) The results of the training that are not optimal are a form of not being properly absorbed by the Batting exercises performed by the coach. 2) The need to adjust the training program adopted from outside as well as the training model and media used in training, to suit the characteristics of the athlete. 3) Batting is the main component for all Cricket athletes. So every beginner athlete in DKI Jakarta U-17 Cricket must master the maximum technique of Batting Cricket.
\end{abstract}

Keywords: Cricket, Batting, Beginner Athletes U-17 


\section{INTRODUCTION}

The trainer is required to have professionalism in training creativity and the ability to master the field which greatly influences the achievement of goals in the training process. The trainer is expected to be able to present effective and varied material so that it can increase the ability and motivate beginner athletes in carrying out training activities, especially performing batting techniques for novice athletes.

Cricket sports for beginner athletes, especially batting techniques are certainly supported by good management and competent coaches and are supported by a good and appropriate training program according to their age in order to achievement for these novice athletes. To produce reliable athletes, it takes a tiered training process and follows a good training program from the coach.

As one of the lecturers who master the field of Cricker sports coaching at the national level, he has the commitment and responsibility to improve the quality of novice athletes in DKI Jakarta. Improving the quality of novice athletes is carried out by analyzing good cricket training programs, especially good batting. The training activity was carried out for 3 months by analyzing cricket training, especially batting (hitting) to improve the quality of young athletes.

Batting in cricket requires motor and psychological skills to play the best shot from a wide repertoire of attacking and defensive strokes against bowlers of diperent types \pm fast, spin, seam and swing (Stretch, Bartlett, \& Davids, 2000). In the cricket sports, batting is collecting scores by hitting the ball and holding the ball and running to swap places with other runners and if the ball hits the stump, the batsman is declared out. In cricket, the person who hits the ball is called a batsman, using a bat, gloves, genital protection pad, and helmet. The main objective of every batsman is to score constantly. In order to do this / he must develop sound technique, learn to concentrate on seeing properly every ball being thrown from the bowler's hand to the bat's surface, and be able to think and play according to think and play according to simple games(Alec Astle, 2004:119).

Exercise is a systematic process and exercises that are carried out repeatedly with each day increasing the amount of training load and training intensity (Tangkudung, 2012). Training as a means to improve performance and reduce the chance for injury (Esser et, al. 2008). Exercise is done with intensity and repetition so that the movement is younger to do. Training is a process for an athlete to prepare and show their best performance (Bompa, 2009). Exercise is also a process that is carried out regularly in order to achieve predetermined goals. The main objective of training in performance sports is to develop biomotor abilities to the highest standards where athletes strive to achieve goal of improving their organ systems and functions to optimize performance both in technical and physical terms.

Weight training is a motoric stimulus (motion) that can be regulated and controlled by coaches and athletes to improve the functional quality of various body equipment. There are two kinds of training loads, namely external loads and internal loads. External loads are motor stimuli that can be regulated and controlled by coaches and athletes by varying weight training through the arrangement of training components such as intensity, volume, recovery, and intervals. Meanwhile, what is meant by internal load is a functional change that occurs in body equipment as a result of the influence of external loads. Changes in the function of body equipment due to the influence of external loads include: (a) morphological (structural) changes in the cross-sectional area of muscle joints, (b) physiological and biochemical changes, namely the pulmonary 
system and blood circulation so that the metabolic process becomes better, and greater vital capacity, and (c) psychological changes, namely the increased ability of athletes to accept stress (pressure), remain concentrated, have mental toughness so that they are able to overcome heavier challenges (obstacles). In the process of achieving maximum performance for an athlete, there are several things that need to be focused on, some of which include; multilateral physical development of specific sports, technical skills, tactical abilities, psychological character, maintaining health and theoretical knowledge.

The objectives of training planning are: 1) to stimulate maximum physiological adaption at specified times during the main competition period; 20 preparing athletes at a complex level of readiness in building skills, biomotor abilities, psychological characteristics, and managing fatigue levels (Lubis, 2013). The aim of training in general to increase the ability and readiness of athletes to reach peak performance. The formulation of training goals and objectives can be for the long term as well as the short term. For the long term are the goals and objectives that will come in the next year or so. This goal is generally a long-term coaching process for junior athletes. The main goal is to enrich the skills of various basic movements and the basics of movement as well as the basics of correct technique. Training will run according to expectations and goals if the program is structured according to what is needed by each athlete. Training is also systematic process that is carried out repeatedly, structured and continuously in order to correct deficiencies in all aspects needed by an athlete to improve his abilities..

The main components needed to vary the exercises are the ratio between (1) work and rest, (2) training models and methods, and light training. Apart from easy to difficult, and from quantity to quality. The adaptation process will occur well if training activities (work) are balanced by rest periods, heavy intensity is balanced with low. Another way to vary the exercises can e by changing the form, place, means and infrastructure of the exercise, or a practice partner. Although the aforementioned elements can be changed, the main purpose of the exercise certainly cannot be changed. Therefore, the training variation emphasizes on maintaining the psychological state of the athlete in order to remain enthusiastic in training. So training is a systematic process to achieve the desired target. Wih systematic training, an athlete can display the maximum performance during the match.

\section{METHODS}

This research is a qualitative descriptive study. Descriptive research is a study that merely describes the state of object (Sutrisno Hadi, 1993: 3), using a survey method, while the data collection technique uses non-test. This research was conducted on Cricket on novice athlete participants aged under 17 in DKI Jakarta. This research was conducted from April to September 2020 with the following stages: proposal submission, committee announcements, signing of work contracts, research, progress reports, monitoring evaluation, and final research report submission. The population in this study were all subject of novice athletes who joined the DKI Jakarta Cricket training.

The instruments used in this study were the batting test and guidelines: Observation; Sugiyono (2014) states that based on the implementation process, observations can be grouped into 2 types, namely participant and non-participant observation. Meanwhile, from the aspect of the instrumentation, observation, observation can be structured and unstructured.

Documentation; Apart from observations and interviews, researchers also need documents to complement the research. 
Emzir said that the documents needed could be in the from of a budget, advertisement, work description, annual report, small notes, school archives, correspondence, biographies, regulations, policies, pictures, videos, or other written data.

Field; According to Moleong (2007), Field notes are notes made by researches while in the field conducting research. These field notes act as a recording device for every event that can be captured by the researchers' five senses.

Triangulation according to Sugiyono (2014) means checking data from various sources in various ways, and at various times. There are 3 forms of triangulation, namely 1) triangulation of data sources (information obtained from several sources), 2) triangulation of data collection techniques (information obtained from the same source but with different techniques) and 3) triangulation of data collection time (data collection at different times).

\section{RESULT AND DISCUSSION}

Batting in cricket requires motor and psychological skills to play the best shot from a wide repertoire of attacking and defensive strokes against bowlers of diperent types \pm fast, spin, seam and swing (Khan, Nicholson, \& Plötz, 2017). Batting in cricket requires the best of motor skills and psychology. Performance is another measure to increase competitveness among players. The probability of a team winning depends on the team's performance. It is revealed that batting capability is the one thatdominates, compared to the other capabilities in winning the game (Harshita Khangarot, Alok Kumar, 2020).

DKI Jakarta U-17 Cricket consists of 60 female and male athletes, which is the result of selection in the development of sports crickets in DKI Jakarta under the guidance of DKI Jakarta Dispora. Tiered coaching is expected to increase the achievement, which is where Cricket has been a sport for a long time in Indonesia, but has only developed in the last ten years, including in DKI Jakarta.

The condition of DKI Jakarta Cricket athletes according to gender can be seen in table

1 below:

Table 1. Distribution of DKI Jakarta Athletes by Gender

\begin{tabular}{cccc}
\hline No & Gender & Amount & Percentage \\
\hline $\mathbf{1}$ & Male & 45 & $75 \%$ \\
$\mathbf{2}$ & Female & 15 & $25 \%$ \\
& Total & 60 & $100 \%$ \\
\hline
\end{tabular}

\section{Description of Batting}

Implementation Test Data

The results of this test are obtained when children join at the beginning of practice using the Batting test in Cricket games. The test results can be presented in table 2 below:

Table 2 Data on batting test for Cricket athletes in DKI U-17

\begin{tabular}{|c|c|c|}
\hline No & Testee & $\begin{array}{c}\text { Percentage } \\
\text { of Batting } \\
\text { Test Results }\end{array}$ \\
\hline 1 & RT & 55,56 \\
\hline 2 & GH & 56,94 \\
\hline 3 & RJ & 56,94 \\
\hline 4 & RB & 56,94 \\
\hline 5 & SR & 51,39 \\
\hline 6 & MA & 55,56 \\
\hline 7 & NG & 54,17 \\
\hline 8 & RA & 58,33 \\
\hline 9 & STA & 61,11 \\
\hline 10 & SD & 55,56 \\
\hline 11 & FE & 55,56 \\
\hline 12 & TRE & 51,39 \\
\hline 13 & CIY & 54,17 \\
\hline 14 & BGS & 50,00 \\
\hline
\end{tabular}


Gladi Jurnal Ilmu Keolahragaan, 12 (01), March- 52

Mastri Juniarto, Rizky Nurulfa

\begin{tabular}{|c|c|c|}
\hline 15 & GPM & 50,00 \\
\hline 16 & KLS & 50,00 \\
\hline 17 & GTR & 48,61 \\
\hline 18 & JKD & 50,00 \\
\hline 19 & STT & 48,61 \\
\hline 20 & $\mathrm{GBH}$ & 50,00 \\
\hline 21 & MAP & 48,61 \\
\hline 22 & JT & 50,00 \\
\hline 23 & WE & 48,61 \\
\hline 24 & PTA & 51,39 \\
\hline 25 & $\mathrm{MNC}$ & 51,39 \\
\hline 26 & $\mathrm{AD}$ & 50,00 \\
\hline 27 & SR & 52,78 \\
\hline 28 & MA & 52,78 \\
\hline 29 & $\mathrm{NG}$ & 52,78 \\
\hline 30 & $\mathrm{RA}$ & 54,17 \\
\hline 31 & STA & 52,78 \\
\hline 32 & SD & 52,78 \\
\hline 33 & $\mathrm{FE}$ & 52,78 \\
\hline 34 & TR & 52,78 \\
\hline 35 & IRK & 56,94 \\
\hline 36 & AS & 54,17 \\
\hline 37 & DF & 50,00 \\
\hline 38 & DW & 48,61 \\
\hline 39 & VS & 55,56 \\
\hline 40 & $\mathrm{BD}$ & 52,78 \\
\hline 41 & NFT & 54,17 \\
\hline 42 & MY & 50,00 \\
\hline 43 & $\mathrm{CE}$ & 51,39 \\
\hline 44 & $\mathrm{CC}$ & 51,39 \\
\hline 45 & MAL & 54,17 \\
\hline 46 & MA & 52,78 \\
\hline 47 & $\mathrm{PE}$ & 58,33 \\
\hline
\end{tabular}

\begin{tabular}{|c|c|c|}
\hline 48 & ULY & 56,94 \\
\hline 49 & MTJ & 52,78 \\
\hline 50 & OP & 50,00 \\
\hline 51 & NP & 54,17 \\
\hline 52 & MIG & 55,56 \\
\hline 53 & DP & 54,17 \\
\hline 54 & BY & 52,78 \\
\hline 55 & RD & 55,56 \\
\hline 56 & AMI & 56,94 \\
\hline 57 & ZR & 59,72 \\
\hline 58 & PDD & 54,17 \\
\hline 59 & GLB & 56,94 \\
\hline 60 & PDK & 56,94 \\
\hline \multicolumn{2}{|c|}{ Average } & 53,36 \\
\hline
\end{tabular}

Based on the table above, it shows that the results of batting for U-17 athletes in DKI Jakarta are $53.36 \%$ on average. These results illustrate that batting is in the moderate category (percentage analysis (Cain, 2014; Khan, 2014)) of U-17 athletes in DKI Jakarta.

This questionnaire analysis suggests two aspects, which is the availability of infrastructure and the implementation of the training carried out by the trainer. Table 3 presents response data from athletes regarding training facilities and infrastructure:

Table 3 Aspects of Completeness of Facilities and Infrastructure

\begin{tabular}{|c|c|c|c|}
\hline No & Statement & Percentage & Explanation \\
\hline 1 & P1 & 92,08 & \\
\hline 2 & $\mathrm{P} 2$ & 92,08 & \\
\hline 3 & P3 & 92,50 & \\
\hline 4 & P4 & 81,67 & \\
\hline 5 & P5 & 78,75 & \\
\hline 6 & P6 & 87,50 & \\
\hline 7 & P7 & 77,92 & \\
\hline 8 & P8 & 91,67 & \\
\hline 9 & P9 & 77,50 & \\
\hline 10 & $\mathrm{P} 10$ & 88,75 & \\
\hline \multicolumn{2}{|r|}{ Average } & 86,04 & Very Good \\
\hline
\end{tabular}

Based on the table above, it shows that the results of the batting training facilities and infrastructure are in DKI Jakarta are $86.04 \%$ on average. These results illustrate that batting facilities and infrastructure are in the very good category (percentage analysis (Cain, 2014; Khan, 2014)) of U-17 athletes in DKI Jakarta.

Table 4 Aspects of The Application of The Exercises Carried Out by The Ttrainer 
Gladi Jurnal Ilmu Keolahragaan, 12 (01), March- 53

Mastri Juniarto, Rizky Nurulfa

\begin{tabular}{|c|c|c|c|}
\hline No & Statement & Percentage & Explanation \\
\hline 1 & P11 & 80,42 & \\
\hline 2 & P12 & 58,75 & \\
\hline 3 & P13 & 64,58 & \\
\hline 4 & P14 & 71,25 & \\
\hline 5 & P15 & 81,67 & \\
\hline 6 & P16 & 81,25 & \\
\hline 7 & P17 & 86,67 & \\
\hline \multicolumn{2}{|c|}{ Average } & 74,94 & Good \\
\hline
\end{tabular}

Based on the table 4 , it shows that the results of the application of the batting training for U-17 athletes in DKI Jakarta are $74.94 \%$ on average. These results illustrate that the application of the batting training are in the good category (percentage analysis (Cain, 2014; Khan, 2014)) of U-17 athletes in DKI Jakarta.

The results of research on batting cricket athletes U-17 DKI Jakarta were conducted to assess how far the development of U-17 training in DKI Jakarta Cricket athletes was. Quality assessment in cricket is a complex task that is performed by understanding the combination of individual activities a player is able to perform and by assessing how well these activities are performed (Khan et al., 2017). Assessment in Cricket with the aim of how well the activity is performed. In the results of batting, DKI Jakarta U-17 athletes averaged $53.36 \%$. These results illustrate that batting is in the moderate category (percentage analysis (Cain, 2014; Khan, 2014)) of U-17 athletes in DKI Jakarta.

Batting in cricket can result in both intended and unintended shots, with both intended and unintended results (Khan et al., 2017).

Some attention is also devoted to batting equipment and to psychological factors in batting (Stretch et al., 2000). An aspect of concern is the equipment for batting. Equipment is included in the category of means in sports, so that the standard or not will greatly affect the quality in training and competition. Therefore, the facilities and infrastructure in sports must be paid close attention. The facilities and infrastructure for batting training for U-17 athletes in DKI Jakarta are on average $86.04 \%$. These results illustrate that batting facilities and infrastructure are in the very good category (percentage analysis (Cain, 2014; Khan, 2014)) of U-17 athletes in DKI Jakarta.

Skill acquisition-motor control specialists are typically grounded in one or more of the theoretical foundations of expertise, that of neuro-motor control or behavioural learning, both of which are fundamental to the assessment of skill and development (Portus \& Farrow, 2011). The application of the training carried out by the trainer greatly influences the improvement of the skills and skills of the athletes, there are many aspects that become benchmarks I their achievement. However, to make athletes comfortable and without pressure in their training, coaches must pay attention and arrange the exercises as attractive as possible, especiall for U-17 athletes who are still in the junior category. The results of the application of batting training for U-17 athletes in DKI Jakarta are $74.94 \%$ on average. These results illustrate that the application of the batting training are in the good category (percentage analysis (Cain, 2014; Khan, 2014)) of U-17 athletes in DKI Jakarta.

\section{CONCLUSION}

The results of the exercise that are not optimal are a form of not properly absorbed by the batting training carried out by the trainer, although in this study it shows the results of the application of the exercise in a good category, but there are 
still some athletes' responses that state that they are not maximal accompanied by facilities that are in the very good category. Maximum exercises. It is necessary to adjust the training program adopted from the outside as well as the training program adopted from the outside as well as the training model and media used in training, to suit the characteristics of the athelete. The batting test results showed that the resut of batting for U-17 athletes in DKI Jakarta are $53.36 \%$ on average. These results indicate that batting in the category is sufficient for the DKI Jakarta U-17 athletes With excellent facilities and infrastructure, the results of training should be even better. The application of the training carried out by the trainer is more responsive to the needs of athletes and pays atttention to aspects of safety and comfort in training.

\section{REFERENCES}

Alec Astle, Coaching a Cricket Team (New Zealand: Spectrum Print, Christchurch, 2004),

Cain, T. (2014). The Sage handbook of action research: participative inquiry and practice. International Journal of Research \& Method in Education. https://doi.org/10.1080/1743727x.20 14.937521

Moleong, Lexy J. Metodologi Penelitian Kualitatif, Penerbit PT Remaja Rosdakarya Offset, Bandung, 2007.

Sugiyono. Metode Penelitian Pendidikan Pendekatan Kuantitatif, Kualitatif Dan R\&D. Bandung: Alfabeta.2014

Emzir.. Metodologi Penelitian Kualitatif Analisis Data. Jakarta. Rajawali Pers.2011

Harshita Khangarot, Alok Kumar., 2020., An Analysis of Batting Performance of the Cricket Players., International Journal of Advanced Science and Technology Vol. 29 , No. 6, (2020), pp. 1574-1579

Lubis, J. (2013). Panduan Praktis Penyusunan Program Latihan. Jakarta: Raja Grafindo
Tudor O Bompa. Periodization theory and methodology of training. (human kinetics.2009)

Esser, T. H. W. N., Uxel, K. E. C. H., Incher, J. E. L. T., \& Kada, T. O. O. (2008). The Relationship Between Core Stability And Performance In Division I Football Players. Journal of Stren, 1750-1754. https://doi.org/10.1519/JSC.0b013e3 181874564

James Tangkudung. Kepelatihan Olahraga. (Jakarta: Cerdas Jaya, 2012)

Alec Astle, Kiwi Cricket (New Zealand: Spectrum Print, 2005)

Cricket Step To Succes (Ralf Dellor: Human Kinetics, 2010)

Official Resource By Cricket (Australia Australia Cricket Coach, 2015)

Ian Pont, Coaching Youth Cricket (USA: Versa Press, 2010)

Ralph Dellor, Cricket step to success ( USA, United Graphics, 2010),

An Official Resource By Cricket Australia, Australian Cricket Coach (Australia,2005)

Khan, A., Nicholson, J., \& Plötz, T. (2017). Activity Recognition for Quality Assessment of Batting Shots in Cricket using a Hierarchical Representation. Proceedings of the ACM on Interactive, Mobile, Wearable and Ubiquitous Technologies, 1(3), 1-31. https://doi.org/10.1145/3130927

Portus, M. R., \& Farrow, D. (2011). Enhancing cricket batting skill: Implications for biomechanics and skill acquisition research and practice. Sports Biomechanics, 10(4), 294-305.

https://doi.org/10.1080/14763141.20 11.629674

Stretch, R. A., Bartlett, R., \& Davids, K. (2000). A review of batting in men's cricket. Journal of Sports Sciences, 18(12), 931-949. https://doi.org/10.1080/02640410044 6748 
